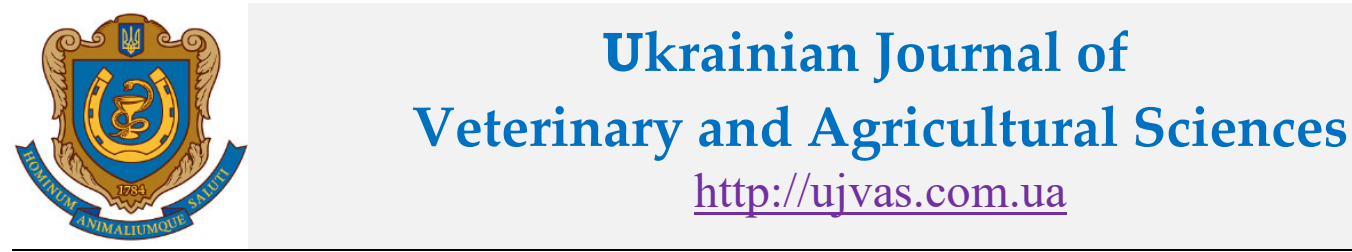

Stepan Gzhytskyi National University of Veterinary Medicine and Biotechnologies Lviv

\begin{tabular}{l|l|l} 
original article & UDC 591.424:639.112 & doi: 10.32718/ujvas4-1.08
\end{tabular}

Volume 4

Number 1

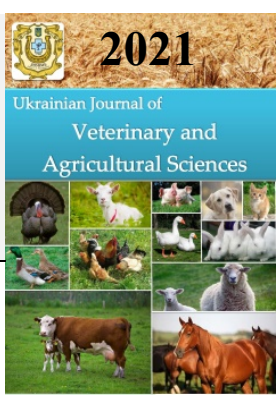

\title{
Features of the macro and microscopic structure of the lungs of a mature rabbit - Oryctolagus cuniculus L. 1758
}

\author{
L. P. Goralskyi ${ }^{1}$, N. M. Glukhova ${ }^{1}$, I. M. Sokulskyi ${ }^{1}$, N. V. Demus ${ }^{2}$ \\ ${ }^{1}$ Polissia National University, Stary Boulevard, 7, Zhytomyr, 10008, Ukraine \\ ${ }^{2}$ Stepan Gzhytskyi National University of Veterinary Medicine and Biotechnologies Lviv, Pekarska Str., 50, Lviv, 79010, \\ Ukraine
}

\begin{tabular}{l} 
Article info \\
Received 18.01.2021 \\
Received in revised form \\
18.02 .2021 \\
Accepted 19.02.2021 \\
\hline Correspondence author \\
Ihor Sokulskyi \\
Tel.: +38-097-785-73-20 \\
E-mail: sokulskiy_1979@ukr.net \\
\hline
\end{tabular}

2021 Goralskyi L. et al. This is an open-access article distributed under the terms of the Creative Commons Attribution License, which permits unrestricted use, distribution, and reproduction in any medium, provided the original author and source are credited.

\section{(cc) BY}

Contents

1. Introduction

2. Materials and methods

3. Results and discussion

4. Conclusions

References ...................... 43

\begin{abstract}
The macro- and microscopic structure of the lungs of mature rabbits - Oryctolagus cuniculus L., 1758 - European rabbit was studied. This work was performed using comprehensive research methods: anatomical, organometric, histological and histometric. The research was carried out in the conditions of the laboratory of pathomorphology in the Department of Anatomy and Histology. The scientific work was performed on the subject of research work of the Department of Anatomy and Histology of Polissya National University on the theme: "Development, morphology and histochemistry of animal organs in normal and pathological", according to the state registration number - № 0113V000900. The morphological studies followed the basic rules of Good Laboratory Practice GLP (1981), the provisions of the "General Ethical Principles of Animal Experiments", adopted by the First National Congress of Bioethics (Kyiv, 2001) and the requirements for the "Rules for carrying out work with experimental animals", approved by the order of the Ministry of Health № 281 of November 1, 2000 "On measures to further improve the organizational forms of work with the use of experimental animals". The material for histomorphological studies were pieces of lungs selected from clinically healthy adult rabbits $(n=5)$. Slices were made from paraffin blocks on a sled microtome MS-2. The thickness of histological sections did not exceed 8-12 $\mu \mathrm{m}$, which were then stained with hematoxylin and eosin and Van Gizon to study the morphofunctional activity of cells and tissues of the respiratory tract. Histometric studies of histological specimens were performed using a microscope "Micros" with a digital camera at a magnification of $\times 100-1000$. Studies have shown that macroscopically the lungs of mature rabbits have a reflection of the shape of the thoracic cavity, and gradually expands ventrally. The right and left lungs are surrounded by pleural right and left sacs. The pleural cavities of both lungs in the test animals are not interconnected. Organometry showed that the absolute lung mass of rabbits is $18.05 \pm 1.32 \mathrm{~g}$, relative to $0.624 \pm 0.013 \%$. The histoarchitectonics of the lungs is formed by the lung lobes. The respiratory department of the lungs is represented by a set of acinuses. The latter are represented by respiratory bronchioles, alveolar passages, alveolar sacs and alveoli that form the alveolar tree. The results of morphometric studies showed that the respiratory (respiratory) part of the lungs of rabbits occupies $39.6 \pm 0.62 \%$, and the connective tissue base, respectively, $58.5 \pm 1.27 \%$. The average volume of alveoli, which are divided into small, medium and large, is $42.3 \pm 4.35$ thousand $\mu^{3}$. Thus, studies of the macro- and microscopic structure of the lungs of experimental animals are of great general biological importance, as they are an important criterion for objective assessment for the differential diagnosis of diseases of various origins.
\end{abstract}

Key words: histomorphology, histological examinations, airways, lung parenchyma, respiratory part of lungs, reduction, respiratory departments, terminal bronchioles, alveoli.

\section{Citation:}

Goralskyi, L. P., Glukhova, N. M., Sokulskyi, I. M., \& Demus, N. V. (2021). Features of the macro and microscopic structure of the lungs of a mature rabbit - Oryctolagus cuniculus L. 1758. Ukrainian Journal of Veterinary and Agricultural Sciences, 4(1), 39-44.

\section{Introduction}

Further development of veterinary medicine is impossible to imagine without morphological modern studies of organs and their systems in domestic animals today (Avtandilov, 1990; Horalskyi et al., 2019). These criteria of morphological research provide researchers with objective tests for processes that occur in biological systems of the body under the influence of various environmental factors and prove the unity of the animal organism with the environment (Stakhiv \& Shemediuk, 2016; Yuskiv \& Shyder,
2018; Bilash et al., 2019). Scientific studies have shown that adaptive changes in humans and animals are closely correlated and depend on the morphofunctional state of organs and tissues (Havrylin \& Hibert, 2018), including the respiratory system.

Actuality of theme: A living organism is characterized by various physiological processes of life, such as gas exchange, nutrition, reproduction, blood circulation, reaction to environmental stimuli, reaction to environmental stimuli, etc. Ensuring such processes is due to the smooth operation of the relevant bodies and systems. The respiratory system is 
one of such system (Horvat \& Dankovych, 2020), which includes the lungs, which perform important functions in the body (Prokushenkova, 2009). Gas exchange between the environment and body tissues, which is manifested in oxygen consumption is one such function of animals (Horalskyi, 1999; Kargopoltseva et al., 2020).

Gas exchange takes place directly in the lungs, between air and blood by the diffusion of oxygen and carbon dioxide through the structure of the wall of the pulmonary alveoli into the blood capillaries. The lungs also play a significant role in such processes as the synthesis of certain hormonelike substances, are actively involved in water-salt and lipid metabolism. The blood deposition occurs in a densely developed vascular arteriolo-venular system (Zhedenov, 1961).

However, despite significant successes and achievements of domestic and foreign morphology of the respiratory system (Vanderelst et al., 2012; Musabayeva et al., 2017), including the lungs (Nozdrachev et al., 2009; Hyde et al., 2009; Tkachenko \& Konovalov, 2010), the morphology of its formation in the phylogenetic series, in terms of comparative characteristics, morphological and morphometric parameters, the study is insufficient. In addition, they are important and priority, which can be used as diagnostic tests and appropriate criteria for physiological norms in various diseases of infectious and non-infectious pathology of animals and humans (Zaytseva et al., 1985; Kryvoruchko, 2002; Nebesna \& Eroshenko 2015). Therefore, the study of the structure of the lungs in domestic animals at the tissue and cellular levels is currently relevant.

The purpose and objectives of the study: To establish the features of macro- and microscopic architectonics of the lungs of a mature rabbit.

\section{Materials and methods}

The research was conducted at the Department of Anatomy and Histology and in the Laboratory of Pathomorphology, Faculty of Veterinary Medicine, Polissya National University. Anatomical, histological, organometric and morphological research methods were used (Avtandilov, 1990; Horalskyi et al., 2019). Dissection of animals was performed in the prosecutor of the relevant department. Morphological studies followed the basic rules of good laboratory practice GLP (1981), the provisions of the "General Ethical Principles of Animal Experiments", adopted by the First National Congress of Bioethics (Kyiv, 2001) and the requirements for the "Rules for carrying out work with experimental animals", approved by the order of the Ministry of Health № 281 of November 1, 2000 “On measures to further improve the organizational forms of work with the use of experimental animals".

The material for histo- and morphological studies were pieces of dissected lungs selected from clinically healthy mature rabbits $(n=5)$. All lung preparations were subject to general anatomical and organometric examination.

The lung material $\left(1 \mathrm{~cm}^{3}\right.$ pieces $)$ were fixed in $10 \%$ neutral formalin solution, followed by pouring in paraffin for histological examination. After fixation and washing of the lung pieces, they were passed through alcohols of increasing strength and xylene then poured into paraffin. From paraffin blocks were made histological sections on a sled microtome $\mathrm{MS}-2$ with a thickness of 9 to $12 \mu \mathrm{m}$.
The results of the research of histological sections in the amount of 36 histopreparations were performed using a light microscope "Micros" (Austria) with a digital camera at a magnification of $\times 100-1000$, according to the recommendations for morphometric studies (Horalskyi et al., 2019).

\section{Results and discussion}

Lungs of rabbits are paired parenchymal organs, located in the thoracic cavity, small in size, pale pink in color, which are divided into right and left.

Externally, the lungs are covered with a serous membrane - visceral pulmonary pleura, which consists of a connective tissue plate, which is formed by thin plexuses of collagen fibers, which are permeated with elastic fibers and cells of the mesothelium - a single layer of squamous epithelium. The pulmonary and parietal pleura form a hermetically sealed pleural cavity in the thoracic cavity, which is filled with a small amount of serous fluid, which reduces the friction of the pleural leaves during inhalation and exhalation.

The lungs of rabbits in their natural state, together with the heart, esophagus, aorta, etc., generally reflect the shape of the thoracic cavity, which gradually expands ventrally. It was found in the organometric study that their absolute weight is $18.05 \pm 1.32 \mathrm{~g}$, relative, respectively, occupies $0.624 \pm 0.013 \%$.

It is known that the right and left lungs are surrounded by right and left pleural sacs, the space between which is cranially limited by the mediastinum, dorsally by the spine, ventrally by the sternum, and caudally by the tendon part of the diaphragm (Parshina \& Musabayeva, 2016). An anatomical feature in rabbits is that the pleural cavities of the right and left lungs do not connect.

Macroscopically, the lungs consist of an enlarged base and a narrowed apex. However, the right lung in rabbits is more developed than the left. It is clearly divided into four lobes with deep notches: apical, cardiac, diaphragmatic and accessory (Fig. 1). The left lung has three lobes: apical reduced, cardiac and diaphragmatic.

According to the results of organometry, the average lung parameters are different: length $-6.8 \pm 0.50$, width $5.5 \pm 0.50$ and thickness $-1.52 \pm 0.20 \mathrm{~mm}$.

At macroscopic research of lungs reduction of an apical lobe of the left lung is observed. The coefficient of asymmetry of both lungs, namely the right to the left, according to their absolute mass is 1.16 . In addition, the left lung is much smaller in weight and volume than the right lung, and is even narrower in shape. Thus, such a lung is less functionally active and less mobile than the right.

According to the literature, studies of the diversity of existing lung forms, their lobular structure and forms of expression of particles in mammals, they are divided and classified into 17 main comparative anatomical types (Zhedenov, 1961). The expressiveness of such lung forms, and their lobular structure, in relation to the division into comparative anatomical types observed in mammals differ in morphofunctional features between animal species and are subject to certain patterns, their adaptive changes in evolution (Zhedenov, 1961). Scientists have proven that the shape of the diaphragmatic lobes of the lungs changes depending on the type of lungs. The lungs have the shape of an irregular cone (Musabayeva et al., 2017). 


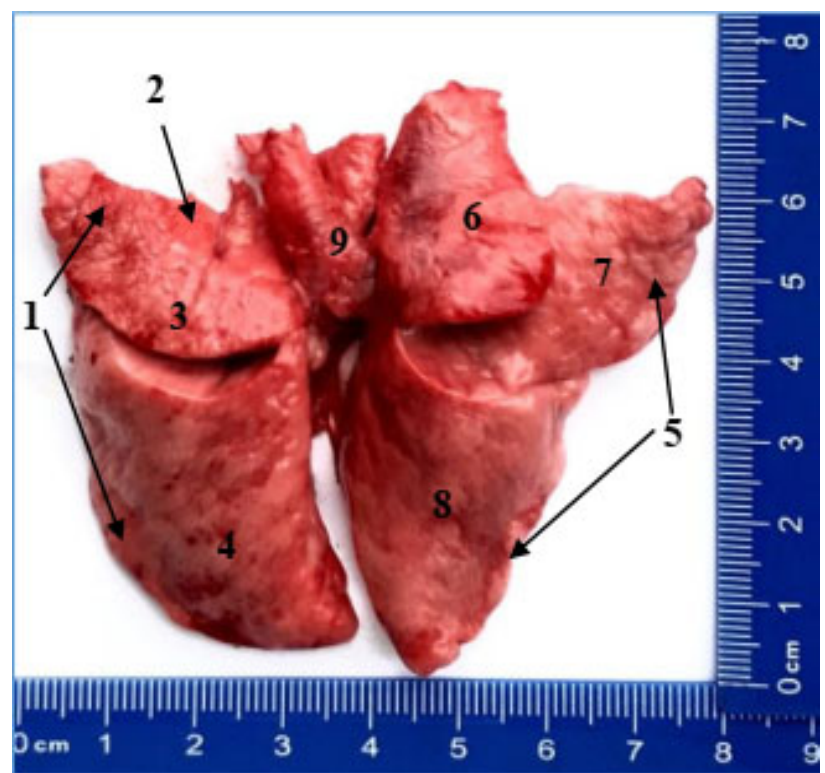

Fig. 1. Macroscopic structure of the lungs of a mature rabbit: 1 - left lung; 2 - reduced apical lobe; 3 - cardiac lobe; 4 - diaphragmatic lobe; 5 - right lung; 6 - apical lobe; 7 - cardiac lobe; 8 - diaphragmatic lobe; 9 - accessory lobe. Macropreparation

At the expressed macroscopic changes, concerning various degree of reduction of the left apical pulmonary lobe at hares allocates three types of lungs: narrowed-extended type; transitional and extended-shortened. Thus, depending on the type, the general shape of the diaphragmatic lobes of the lungs changes significantly, namely their shortening or elongation. On the lungs of rabbits there are: diaphragmatic, costal, medial and interlobar surfaces and obtuse dorsal and acute ventral and basal edges and cardiac notch.

According to our morphometric and organometric studies, according to the classification of the lungs (Zhedenov, 1961), the lungs of rabbits belong to type VIII: they have almost complete pronounced reduction - atrophy with preservation of the process of the left apical lobe with clear expression of all other lobes in the right and left lungs. In addition, the right lung includes the apical, cardiac, accesso-

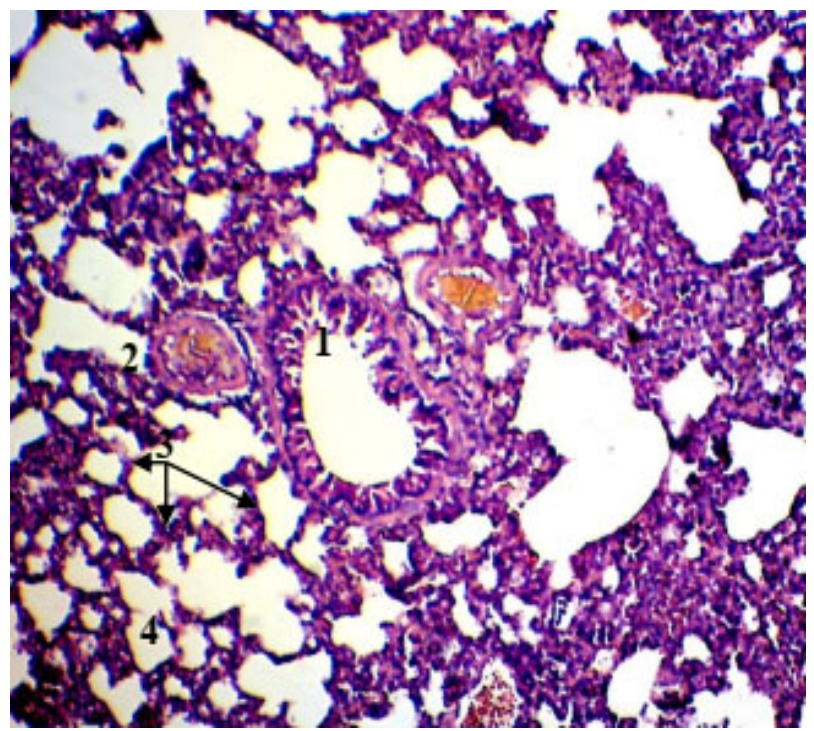

Fig. 3. Fragment of the histological structure of the lungs of a mature rabbit: 1 - small bronchus; 2 - vessels;

3 - alveolar septum; 4 - alveoli. Hematoxylin and eosin. X. 120.

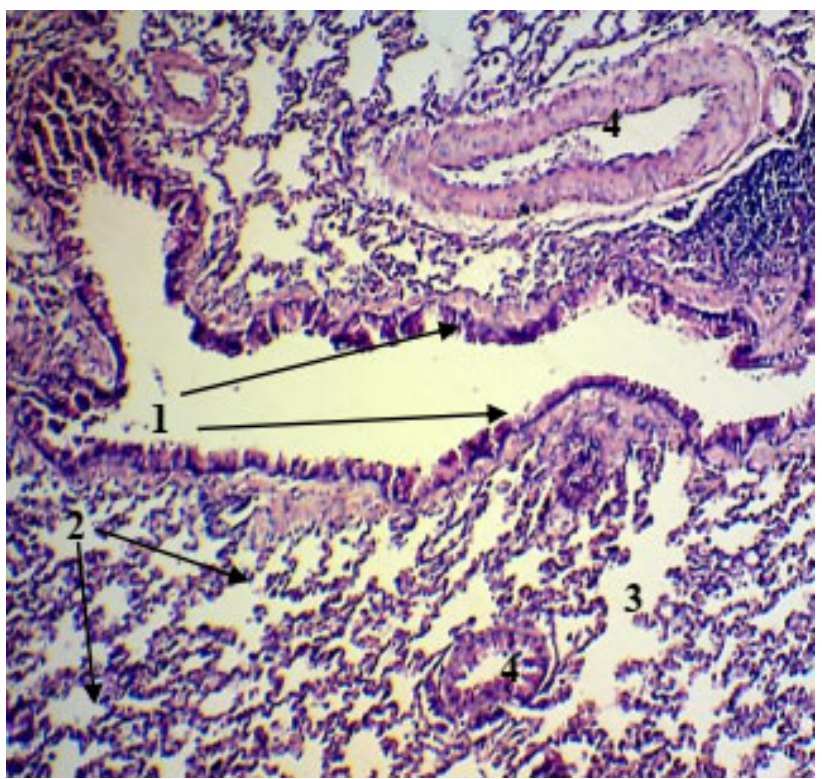

Fig. 2. Fragment of the histological structure of the lung of a mature rabbit: 1 - longitudinal section of the small bronchus; 2 - alveolar sacs; 3 - alveolar ducts; 4 - vessels. Hematoxylin and eosin. X 120

ry and most pronounced diaphragmatic lobe, which is due to the morphofunctional type of respiration of the studied animals.

The internal morphological structure of lung tissue is formed by pulmonary particles that have a conical or pyramidal shape: these are small areas of the lung parenchyma, separated by connective tissue septa, which form the connective tissue stroma of the lungs. The connective tissue stroma is formed by loose connective tissue and contains elastic fibers, blood and lymphatic vessels. When staining histopreparations by the Van Gizon method, collagen fibers are detected in the connective tissue stroma, which are stained with red dyes.

A significant proportion of lung tissue is their parenchyma (Fig. 2) - the airways and respiratory tract, which accompany blood vessels and nerves.

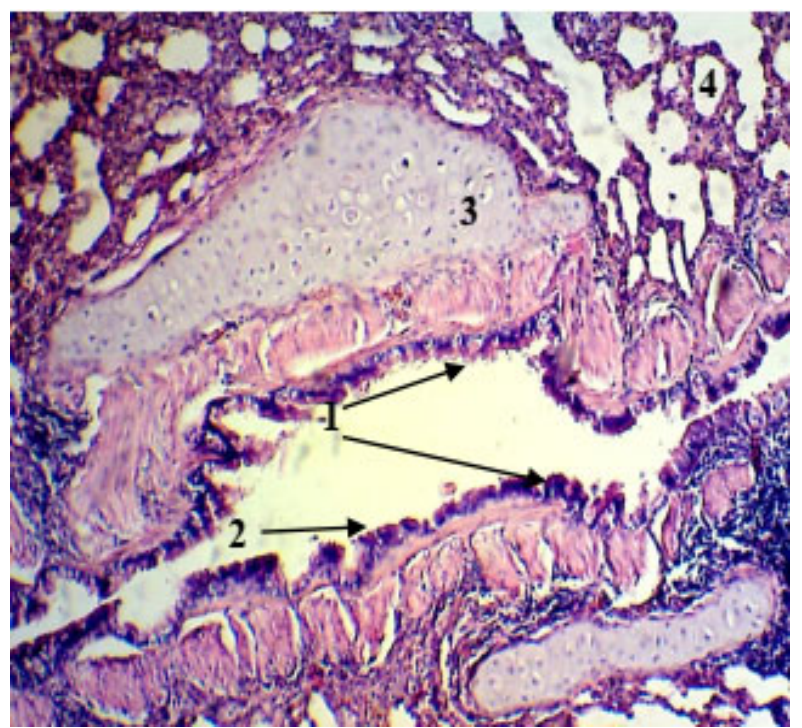

Fig. 4. Fragment of the histological structure of the lungs

of a mature rabbit: 1 - large bronchus; 2 - multi-row

ciliated epithelium; 3 - cartilaginous islands; Hematoxylin and eosin. X 120. 
The air-carrying system of the lungs is formed by branched bronchi and terminal bronchioles. The main bronchi enter to the lung parenchyma and give rise to the pulmonary bronchi of different diameters (Fig. 3). The latter, depending on the diameter and their structure, are divided into large, medium, small and terminal bronchioles. Pulmonary bronchi form a bronchial tree. The structure of the wall of the main bronchi is similar to the wall of the trachea and is built of mucous, fibrocartilage and adventitia. The epithelial plate of the bronchial mucosa of large and medium calibers is represented by multi-row ciliated epithelium, in bronchi of small caliber it is replaced by two-row.

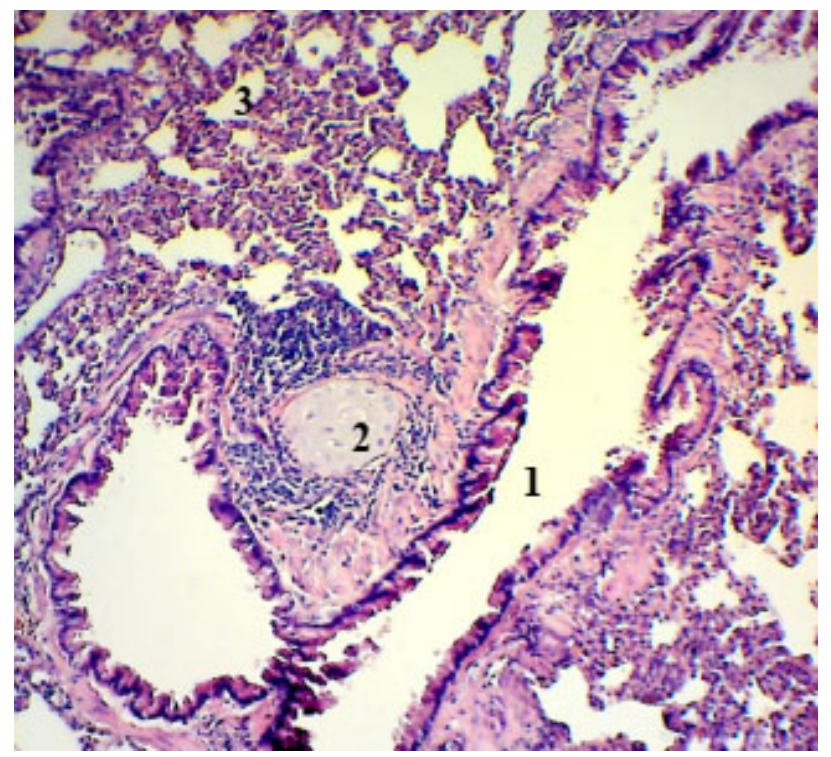

Fig. 5. Fragment of the histological structure of the lungs of a mature rabbit: 1 - lumen of the middle bronchus; 2 islet of cartilaginous tissue; 3 - alveoli; Hematoxylin and eosin. X. 120

The cartilaginous tissue is almost absent in bronchi with medium caliber and it is found only in the form of individual cartilaginous islands, which are small (Fig. 5). Their mucous membrane is covered with a single layer of multilayered respiratory epithelium. Cartilage and glands are absent in the bronchi of small caliber. Their mucous membrane is lined with a single layer of ciliated epithelium. They branch into terminal bronchioles.

Respiratory lung parenchyma is formed by respiratory bronchioles, alveolar ducts and alveolar sacs, in the walls of which are alveoli that form the alveolar tree (Fig. 6). The alveoli are lined with a single layer of squamous epithelium (Fig. 7), which is located on the basement membrane. A network of blood capillaries with endothelium is tightly adjacent to the basement membrane externally. Such morphological structures: respiratory bronchioles, alveolar ducts, which pass into the sacs as a whole, form a morphofunctional unit - acinuses.

Respiratory bronchioles in the lung parenchyma are formed as a result of their branching into terminal bronchioles, alveolar ducts - due to the division of respiratory bronchioles of the second and third orders, alveolar sacs, which
Detailed studies have shown that the diameter of the bronchi varies significantly from size (Koptiev, 2011). Thus, as the diameter of the bronchi decreases, their diameter and wall thickness decrease (Dzhadranov et al., 2016). According to the results of our histological examinations, the inner wall of the large bronchi is lined with multi-row ciliated epithelium; the cartilaginous plates of various sizes and shapes are in their walls. They form so-called cartilaginous islands (Fig. 4). A muscular plate is found in the mucous membrane throughout the lumen of such bronchi.

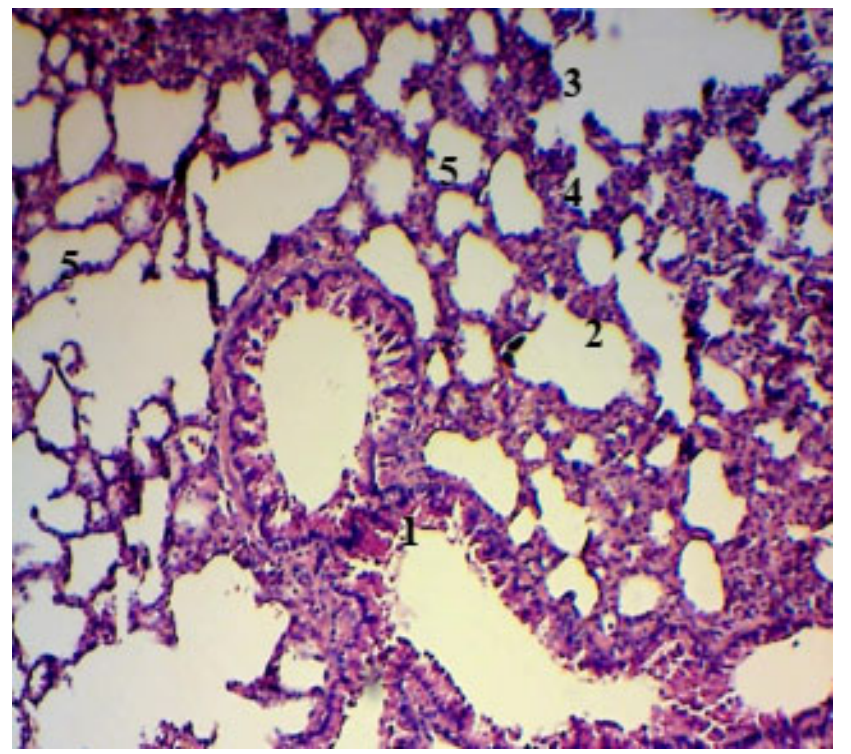

Fig. 6. A fragment of the histological structure of the respiratory parenchyma of the lungs of a mature rabbit: 1 - bronchioles; 2 - alveolar sacs; 3 - alveolar ducts; 4 alveoli; 5 - alveolar septa; Hematoxylin and eosin. X. 120

are the blind end of the alveolar ducts. The wall of the respiratory tract is formed by alveolocytes - respiratory, secretory and alveolar macrophages (phagocytose dust particles, microorganisms, fragments of surfactant fluid and participate in immune reactions) (Golohvast \& Chaika, 2011). The interalveolar membranes of the histostructure of the lungs of rabbits are clearly expressed and formed by layers of loose connective tissue.

Based on the analysis of our morphometric data, the respiratory part of the lungs of mature rabbits is $39.6 \pm 0.62 \%$ of the total organ area. The connective tissue base is equal to $58.4 \pm 1.27 \%$, respectively (Fig. 8). The pulmonary alveoli that form the respiratory part have different sizes: small, medium and large, the average volume of which is $42.3 \pm 4.35$ thousand $\mu \mathrm{m}^{3}$.

Thus, the results of our morphological studies indicate that the morphology of the lungs of rabbits has certain features of their macro- and microscopic structure and characteristic indicators, compared with other species of domestic animals of the class "mammals", the results of which can be used as indicators in the diagnosis of respiratory diseases genesis. 


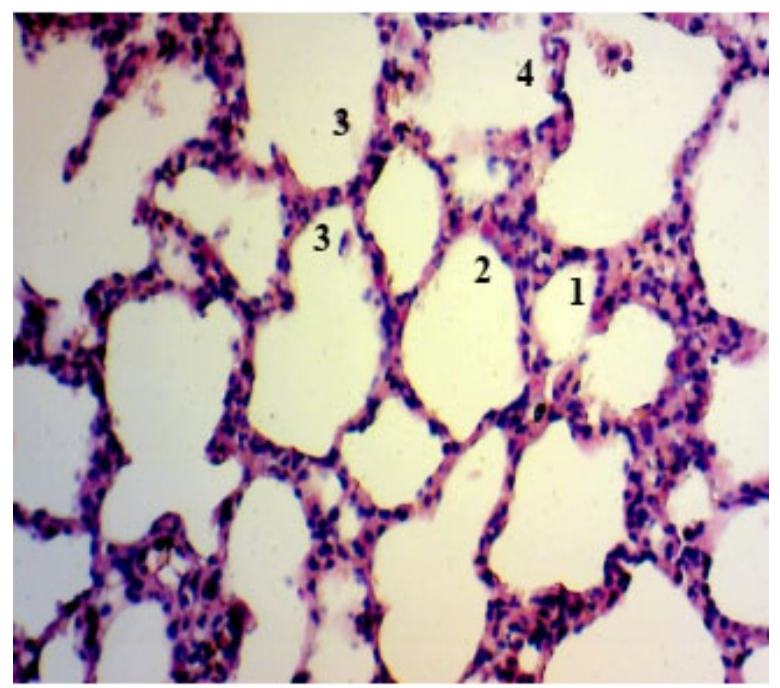

Fig. 7. Histological structure of the lungs of a mature rabbit; 1 - lumen of the small alveoli; 2 - lumen of the middle alveolus; 3 - lumen of the large alveoli; 4 - interalveolar membranes. Hematoxylin and eosin. X. 280

\section{Conclusions}

As a result of morphological studies, rabbit lungs according to morphological classification belong to type VIII: they have almost complete atrophy (reduction) with preservation of the process of the left apical lobe with a clear expression of all other lobes in the right and left lungs. In particular, the right lung includes the apical, cardiac, accessory and most pronounced diaphragmatic lobes, the left lobe has a reduced apical, cardiac and diaphragmatic, which is due to the type of respiration of this species.

Morphometric studies have shown that the respiratory part of the lungs of a mature rabbit is $39.6 \pm 0.62 \%$, connective tissue base $-58.5 \pm 1.27 \%$, and the average volume of the alveoli is $42.3 \pm 4.35$ thousand $\mu \mathrm{m}^{3}$.

Prospects for further research are aimed at ultramicroscopic examination of the respiratory part of the lungs of mature rabbits.

\section{Conflict of interest}

The authors declare that there is no conflict of interest.

\section{References}

Avtandilov, G. G. (1990). Morfometricheskaya morfometriya. Moskva: Meditsina (in Russian).

Bilash, S. M., Pronina, O. M. \& Koptev, M. M. (2019). Znachennia kompleksnykh morfolohichnykh doslidzhen dlia suchasnoi medychnoi nauky. Ohliad literatury. Vistnyk problem biolohii $i$ medytsyny, 2(2), 20-22. doi: 10.29254/2077-4214-2019-2-2151-20-23 (in Ukrainian).

Dzhadranov, E. S., Ergazina. M. Zh., Ibadullayeva, F. S., Krasnoshtanov, A. V., Krasnoshtanov, V. K. \& Zhumabayeva, Zh. K. (2016). Strukturnyye osobennosti legochnoy tkani nekotorykh vidov laboratornykh zhivotnykh. Vesnik Kazakhskogo Natsionalnogo meditsinskogo universiteta, 3, 1-4 (in Russian).

Golokhvast, K. S. \& Chayka, V. V. (2011). Alveolyarnyy makrofag (kratkiy obzor). Vestnik novykh meditsinskikh tekhnologiy, 18(2), 23-24 (in Russian).

Havrylin, P. M., \& Hibert, I. I. (2018). Zakonomirnosti kilkisnoi dynamiky tkanynnykh komponentiv limfatychnykh vuzliv kroliv miasnoho napriamku vykorystannia. Naukovyi visnyk Lvivskoho natsionalnoho universytetu veterynarnoi medytsyny

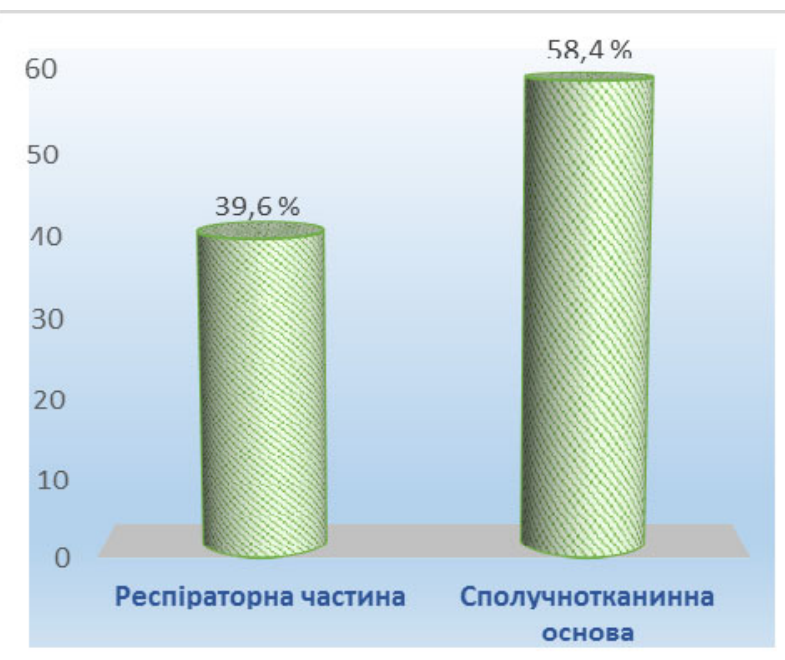

Fig. 8. Area of histostructures of lungs of mature rabbits

ta biotekhnolohii imeni S. Z. Gzhytskoho, 20(83), 3-5. doi: 10.15421/nvlvet8301 (in Ukrainian).

Horalskyi, L. P. (1999). Morfometrychna kharakterystyka lehen silskohospodarskykh tvaryn. Naukovyi visnyk Natsionalnoho ahrarnoho universytetu, 16, 39-42 (in Ukrainian).

Horalskyi, L. P., Demus, N. V., Khomenko, Z. V., Sokulskyi, I. M. \& Nikitina, Yu. O. (2019). Osoblyvosti pechinky statevozriloi sobaky. Naukovyi visnyk Lvivskoho natsionalnoho universytetu veterynarnoi medytsyny ta biotekhnolohii imeni S. Z. Gzhytskoho. Seriia: Veterynarni nauky, 21 (94), 61-64. doi: 10.32718/nvlvet9411 (in Ukrainian).

Horalskyi, L. P., Khomych, V. T., \& Kononskyi, O. I. (2019). Osnovy histolohichnoi tekhniky i morfofunktsionalni metody doslidzhennia u normi ta pry patolohii. Zhytomyr: Polissia (in Ukrainian).

Horvat, M. P., \& Dankovych, R. S. (2020). Morfolohichna kharakterystyka orhaniv dykhannia i travlennia vynohradnoho ravlyka (Helix pomatia L., 1758). Naukovyi visnyk Lvivskoho natsionalnoho universytetu veterynarnoi medytsyny ta biotekhnolohii imeni S. Z. Gzhytskoho. Seriia: Veterynarni nauky, 22(97), 7-9. doi: 10.32718/nvlvet9702 (in Ukrainian).

Hyde, D. M., Hamid, Q. \& Irvin, C. G. (2009). Anatomy, pathology, and physiology of the tracheobronchial tree: emphasis on the distal airways. Journal of Allergy and Clinical Immunology, 124(6), 72-77. doi: 10.1016/j.jaci.2009.08.048.

Kargopoltseva, D. R., Katelnikova, A. E., Kryshen, K. L. \& Gushchin, Ya. A. (2020). Osobennosti dykhatelnoy sistemy zhivotnykh. ispolzuyemykh $\mathrm{v}$ doklinicheskikh issledovaniyakh. kotoryye neobkhodimo uchityvat pri modelirovanii patologiy legkikh. Laboratornyye zhivotnyye dlya nauchnykh issledovaniy, 4, 71-77. doi: 10.29296/2618723X (in Russian).

Koptiev, M. M. (2011). Morfo-funktsionalna kharakterystyka strukturnykh elementiv lehen shchuriv u normi. Visnyk VDNZU "Ukrainska medychna stomatolohichna akademiia", 11(4), 92-94 (in Ukrainian).

Kryvoruchko, O. H. (2002). Vikovi i reaktyvni osoblyvosti limfoidnykh utvoren lehen (Avtoreferat dysertatsii kandydata biolohichnykh nauk). Natsionalnyi medychnyi universytet im. O. O. Bohomoltsia, Kyiv (in Ukrainian).

Musabayeva, L. L., Seitov, M. S., \& Parshina, T. Yu. (2017). Sravnitelnyye aspekty morfologii serdtsa i legkikh zaytsarusaka i krolika domashnego (molochnyy vozrastnoy period). Almanakh molodoy nauki, 4, 32-35 (in Russian).

Nebesna, Z. M., \& Yeroshenko, H. A. (2015). Histolohichni ta histokhimichni zminy lehen pry eksperymentalnii termichnii travmi. Svit medytsyny ta biolohii, 2(49), 106-109 (in Ukrainian). 
Nozdrachev, A. D., Polyakov, E. L. \& Fedin, A. N. (2009). Anatomiya krolika. Sankt-Peterburg: Izdatelstvo SanktPeterburgskogo universiteta (in Russian).

Parshina, T. Yu., \& Musabayeva, L. L. (2016). Anatomotopograficheskaya kharakteristika legkikh krolika domashnego (Oryctolagus cuniculus). Izvestiya Orenburgskogo gosudarstvennogo agrarnogo universiteta, 1(57), 199-201 (in Russian).

Prokushenkova, O. H. (2009). Morfolohiia lehen tsutseniat sobak Neonatalnoho periodu. Naukovyi visnyk Lvivskoho natsionalnoho universytetu veterynarnoi medytsyny ta biotekhnolohii imeni S. Z. Gzhytskoho, 11(2), 244-247 (in Ukrainian).

Stakhiv, O., \& Shemediuk, N. P. (2016). Telomerna teoriia starinnia klityny. Naukovyi visnyk Lvivskoho natsionalnoho universytetu veterynarnoi medytsyny ta biotekhnolohii imeni S. Z. Gzhytskoho, 18(3), 109-112. doi: 10.15421/nvlvet7125 (in Ukrainian).

Tkachenko, L. V., \& Konovalov, V. S. (2010). Topografiya legkikh polovozrelogo krolika v norme. Vestnik Altayskogo gosu- darstvennogo agrarnogo universiteta, 8(70), 55-60 (in Russian).

Vanderelst, D., Jonas, R., \& Herbert, P. (2012). The furrows of Rhinolophidae revisited. Journal of the Royal Society, Interface the Royal ociety, 9(70), 1100-1103. doi: 10.1098/rsif.2011.0812.

Yuskiv, I. D., \& Shyder, Ye. I. (2018). Efektyvnist ivermektynu za psoroptozu kroliv i yoho vplyv na systemu antyoksydantnoho zakhystu ta perekysne okysnennia lipidiv. Visnyk Poltavskoi derzhavnoi ahrarnoi akademii, 4, 189-191. doi: 10.31210/visnyk2018.04.30 (in Ukrainian).

Zaytseva, K. K., Simonenkova, V. A., \& Komar, Yu. A. (1985). Ultrastrukturnaya organizatsiya aerogematicheskogo baryera legkikh laboratornykh zhivotnykh. Arkhiv anatomii, gistologii $i$ embriologii, 9, 59-66 (in Russian).

Zhedenov, V. N. (1961). Legkiye i serdtse zhivotnykh i cheloveka ( $v$ estestvenno-istoricheskom razvitii). Moskva: Vysshaya shkola (in Russian). 